\title{
COVID-19 Pandemic: Impacts on Small Businesses, Tourism, and International Students Globally: A Review
}

\author{
Zhanna Dossan* \\ PhD Candidate \\ School of Political Science and Public Administration, \\ Wuhan University, Wuhan, Hubei, 430072 China
}

\begin{abstract}
COVID 19 pandemic has substantially affected the globalized world. It has emerged as the black swan subsequent to the economic crisis of World War II, which has had a rippled effect on the healthcare sector as well as business infrastructure globally. To analyze the impact it has had on the overall globalized world, this research was performed. Using the descriptive research design, this research assessed the impact of COVID 19 on small businesses, tourism, as well as international students. The survey was performed where the individuals from different demographic backgrounds were analyzed. This included the individuals belonging to the small businesses, the tourism sector, as well as the educational sector with operations that are held internationally. The survey showed that individual across the three-sector has substantially been affected. This was due to the restricted mobilization, which affected the trade as well as traveling. The international students further experienced emotional distress and found their life to be affected. However, the research also revealed that the businesses that worked online proliferated as a result of COVID 19.
\end{abstract}

Keywords: COVID-19 Pandemic, Small Businesses, Tourism, International Student.

DOI: $10.7176 / \mathrm{EJBM} / 13-6-09$

Publication date:March $31^{\text {st }} 2021$

\section{Introduction}

It is well-established that COVID 19 has had a substantial adverse impact across the different sectors of the world (Gössling, Scott, \& Hall, 2020). The pandemic was first declared by the World health organization, where the confirmed cases were found to be initially at 200 000, with an exceeding death tool of 8000 across the 1600 countries in the world. Initially, China was affected by it, which further followed Italy, and then Europe, spreading across the different regions of the world (Xiong et al., 2020). Studies have presented that the economies (nationally) are substantially affected by the international, regional as well as local travel restrictions such as the domestic tourism, day visits, international travel, along with different segments such as the air transport, the cruise, public transport, accommodation as well as conventions, meetings, festivals as well as sports events (Gössling, Scott, \& Hall, 2020). With the slowdown of international travel, various countries are also observing international travel bans, closing of the borders, as well as introducing the quarantine periods, international and domestic tourism, which precipitously declined within weeks. Different countries have scrambled to return to the travelers' homes, which is a similar case for the outbound markets involved hundreds of thousands of citizens across the different parts of the world (Xiong et al., 2020). Thakur \& Jain (2020) research had further found that, Spain experience a decrease in the international arrivals by 10.8 million, Thailand experience 7.3 million decreases, Turkey 4.4 million, Singapore, Mexico, Italy, Vietnam experienced 3.6 million each, and United State 3.1 million and Austria 3.2 million.

Accordingly, the uncertainties as well as fears linked with the virus outbreak, along with the mass lockdown as well as the economic recession, had further predicted to lead to the economic downturn, as well as the different psychological impact on the individuals. For instance, researchers have found that the economic recession has increased the rate of suicide and the mental disorder among individuals. This is further amplified by the research of McIntyre and Lee (2020), which found that among the Canadian individual, joblessness as a result of the pandemic has led to an increase from 418 to 2114 among individuals. Similar findings have been reported by the other researches, which show that the pandemic has lead to increasing risk for the suicide, such as that in the USA, India, Pakistan, Germany, France as well as Italy (Thakur and Jain, 2020; Mamun \& Ullah, 2020). A plethora of researches have shown that the pandemic has led to increased psychological as well as economic stress on the healthcare personnel as well as business entrepreneur (Tan et al., 2020; Hao et al., 2020; Wang et al., 2020). This calls for an urgent call given to the need for the development of the public mental health as well as the policies that aid individuals in challenging times. To assess the effect of COVID 19 on the different aspects of the individual life, the following research questions have been formulated.

- What is the impact of the COVID 19 pandemic on the small businesses?

- What is the impact of the COVID 19 pandemic on the tourism sector?

- What is the impact of the COVID 19 pandemic on the international students?

The further research is organized into five sections, each presenting its own aim and objectives. This includes 
the analysis of the design and methods, the sample selected for the research, the variables used, as well as statistical analysis that is carried out in the research. The third part of the research presents the results gathered from the selected sample, as well as analysis of the socio-demographic explanation. The fourth part provides the discussion related to the findings, whereas the last part summarizes the overall findings, highlighting the limitations as well as determining the future research area.

\section{Materials and Methods}

\subsection{Study Participants and Procedure}

For this research, in particular, the research design of exploratory is used. Similar to these, more researches have also used the same research design promoting the inclusion of the same research design in the present study (Hooda \& Ankur, 2018; Buchanan, Kelly, \& Yeatman, 2017). These researches reinforce the idea that the design is effective for getting a more thorough understanding concerning the interest of the target population, their attitude, standpoint as well as opinions related to the research subject. The population of this research comprise of the international students, small business individuals as well as the tourist. The researcher determination is dependent on the individual specific need concerning the age of the participants, the gender, experience, and more (Kumar, 2019). In the present research design, the research sampling technique that is used is that of the nonprobability sampling design. For instance, the Taherdoost (2016) research has shown that the non-probability sampling technique assists in narrowing down the methods that are deployed by the researcher.

\subsection{Measures}

The collection of the data is held by the use of the primary data. This indicates that the collection of the data from scratch (Kumar, 2018). This primary data is collected by conducting the survey. The survey is held online with the use of a close-ended questionnaire. The major reason for the collection of the data is that it is simple, economical as well as time effective. Another reason for the collection of the research using a survey design is that it helps in the collection of the data from a large population. This is effective in the collection of the quantitative data as compared to the qualitative data. Earlier researches, for instance, Kumar (2018) is found to illustrate the effectiveness of the online survey for reaching effective results, which is less complicated. The research instrument that this research uses is the 5-point Likert scale which comprises of the responses ranging from strongly agree to strongly disagree. The use of this research design is effective for reaching conclusive results. However, prior to the collection, the ethical approval was acquired from the ethical committee of the institute. The questionnaire is used online following the determination of its reliability and validity. The Cronbach alpha value is determined by the analysis of the research instrument validity and reliability. The main reason used is that this is effective for ensuring the reliability and consistency of the used questionnaire (Brown, 2002). The questionnaire validity is determined by consulting one language expert as well as the consultation from three social science experts.

\subsection{Statistical Analysis}

The gathered data is used for the analysis by the deployment of the IBM statistical software such as Statistical Package for Social Sciences (SPSS). The software is used for the analysis of the responses through the computation of the descriptive analysis, Pearson correlation, as well as the multiple regression analysis of the determined study variables (with a determined value of $p$-value of less than 0.05 ).

\subsection{Ethical Considerations}

With regard to this research, the investigator will make sure that each stage of the research is conducted properly and ethical problem is raised in the completion of the research analysis. For the purpose, all the research participants will be told honestly regarding the purpose of the research and no individual will be compelled to take part in the survey (Habib et al., 2014). Other crucial ethical aspects like confidentiality and privacy of information and free consent of the respondents will be effectively ensured. Apart from this, unbiased opinions of the respondents will be encouraged in order to fulfill the research objectives in a successful manner. In context of the secondary data, permission will be taken from the authors and writers of the journals and articles, wherever possible, for eliminating any sort of copyright problems. Moreover, the researcher will ensure that use of secondary sources does not result in any harm or distress to any member of the research team.

\section{Results}

The socio-demographic analysis of the respondents suggested that most of the respondents were males, while the number of females was low ( $\mathrm{n}-357$ and n-143, respectively). Further analysis of the age provided that most of the participants were aged from 29 to 39 years (n-220). The second major group was identified to be aged from 40 to 50 years, as well as 18 to 28 years. The education analysis further indicated that most of the individuals were either graduate or masters, given the close by of the provided responses. The working years show that less than one year of experience was of 112 employees, while other had experience more than this. Most the respondents 
belonged to the Asia continent, where the number of individual belonging to tourist sector was most prominent. Table 1: Socio-Demographic Analysis of the Participants

\begin{tabular}{|c|c|c|c|c|c|}
\hline \multicolumn{6}{|c|}{ Gender } \\
\hline & & Frequency & Percent & Valid Percent & $\begin{array}{l}\text { Cumulative } \\
\text { Percent }\end{array}$ \\
\hline \multirow[t]{3}{*}{ Valid } & Male & 357 & 71.4 & $\begin{array}{r}71.4 \\
\end{array}$ & 71.4 \\
\hline & Female & 143 & 28.6 & 28.6 & 100.0 \\
\hline & Total & 500 & 100.0 & 100.0 & \\
\hline \multicolumn{6}{|c|}{ Age } \\
\hline & & Frequency & Percent & Valid Percent & $\begin{array}{l}\text { Cumulative } \\
\text { Percent }\end{array}$ \\
\hline \multirow[t]{5}{*}{ Valid } & 18 to 28 years & 84 & 16.8 & 16.8 & 16.8 \\
\hline & 29 to 39 years & 220 & 44.0 & 44.0 & 60.8 \\
\hline & 40 to 50 years & 127 & 25.4 & 25.4 & 86.2 \\
\hline & 51 and above years & 69 & 13.8 & 13.8 & 100.0 \\
\hline & Total & 500 & 100.0 & 100.0 & \\
\hline \multicolumn{6}{|c|}{ Education } \\
\hline & & Frequency & Percent & Valid Percent & $\begin{array}{l}\text { Cumulative } \\
\text { Percent }\end{array}$ \\
\hline \multirow[t]{5}{*}{ Valid } & Undergraduate & 57 & 11.4 & 11.4 & 11.4 \\
\hline & Graduates & 286 & 57.2 & 57.2 & 68.6 \\
\hline & Masters & 106 & 21.2 & 21.2 & 89.8 \\
\hline & Others & 51 & 10.2 & 10.2 & 100.0 \\
\hline & Total & 500 & 100.0 & 100.0 & \\
\hline \multicolumn{6}{|c|}{ Working Years } \\
\hline & & Frequency & Percent & Valid Percent & $\begin{array}{c}\text { Cumulative } \\
\text { Percent }\end{array}$ \\
\hline \multirow[t]{5}{*}{ Valid } & Less than two years & 112 & 22.4 & 22.4 & 22.4 \\
\hline & two years to nine years & 346 & 69.2 & 69.2 & 91.6 \\
\hline & $\begin{array}{l}\text { Ten years to fifteen } \\
\text { years }\end{array}$ & 32 & 6.4 & 6.4 & 98.0 \\
\hline & More than fifteen years & 10 & 2.0 & 2.0 & 100.0 \\
\hline & Total & 500 & 100.0 & 100.0 & \\
\hline \multicolumn{6}{|c|}{ Continent } \\
\hline & & Frequency & Percent & Valid Percent & $\begin{array}{c}\text { Cumulative } \\
\text { Percent }\end{array}$ \\
\hline \multirow[t]{7}{*}{ Valid } & Africa & 109 & 21.8 & 21.8 & 21.8 \\
\hline & Asia & 125 & 25.0 & 25.0 & 46.8 \\
\hline & Europe & 103 & 20.6 & 20.6 & 67.4 \\
\hline & North America & 67 & 13.4 & 13.4 & 80.8 \\
\hline & Oceania & 41 & 8.2 & 8.2 & 89.0 \\
\hline & South America & 55 & 11.0 & 11.0 & 100.0 \\
\hline & Total & 500 & 100.0 & 100.0 & \\
\hline \multicolumn{6}{|c|}{ Respondents } \\
\hline & & Frequency & Percent & Valid Percent & $\begin{array}{c}\text { Cumulative } \\
\text { Percent }\end{array}$ \\
\hline \multirow[t]{4}{*}{ Valid } & Students & 170 & 34.0 & 34.0 & 34.0 \\
\hline & \multirow{2}{*}{$\begin{array}{l}\text { Tourism Related Individu } \\
\text { Small Business Owners }\end{array}$} & 179 & 35.8 & 35.8 & 69.8 \\
\hline & & 15 & 30.2 & 30.2 & 100.0 \\
\hline & Total & 50 & 100.0 & 100.0 & \\
\hline
\end{tabular}

\section{Impact on Small Businesses}

Participants have agreed that different COVID 19 factors impacting small businesses 
Table 2: COVID 19 factors impacting small businesses

\begin{tabular}{|c|c|c|c|c|c|}
\hline \multicolumn{6}{|c|}{ Financial and Supply Loss } \\
\hline & & Frequency & Percent & Valid Percent & Cumulative Percent \\
\hline \multirow[t]{5}{*}{ Valid } & Strongly Agree & 66 & 13.2 & 13.2 & 13.2 \\
\hline & Agree & 338 & 67.6 & 67.6 & 80.8 \\
\hline & Neutral & 36 & 7.2 & 7.2 & 88.0 \\
\hline & Disagree & 60 & 12.0 & 12.0 & 100.0 \\
\hline & Total & 500 & 100.0 & 100.0 & \\
\hline \multicolumn{6}{|c|}{ Employee health } \\
\hline & & Frequency & Percent & Valid Percent & Cumulative Percent \\
\hline \multirow[t]{5}{*}{ Valid } & Strongly Agree & 21 & 4.2 & 4.2 & 4.2 \\
\hline & Agree & 389 & 77.8 & 77.8 & 82.0 \\
\hline & Neutral & 39 & 7.8 & 7.8 & 89.8 \\
\hline & Disagree & 51 & 10.2 & 10.2 & 100.0 \\
\hline & Total & 500 & 100.0 & 100.0 & \\
\hline \multicolumn{6}{|c|}{ Immobility } \\
\hline & & Frequency & Percent & Valid Percent & Cumulative Percent \\
\hline \multirow[t]{5}{*}{ Valid } & Strongly Agree & 33 & 6.6 & 6.6 & 6.6 \\
\hline & Agree & 375 & 75.0 & 75.0 & 81.6 \\
\hline & Neutral & 37 & 7.4 & 7.4 & 89.0 \\
\hline & \begin{tabular}{|l|} 
Disagree \\
\end{tabular} & 55 & 11.0 & 11.0 & 100.0 \\
\hline & Total & 500 & 100.0 & 100.0 & \\
\hline \multicolumn{6}{|c|}{ Unemployment } \\
\hline & & Frequency & Percent & Valid Percent & Cumulative Percent \\
\hline \multirow[t]{4}{*}{ Valid } & \begin{tabular}{|l|} 
Strongly Agree \\
\end{tabular} & 15 & 3.0 & 3.0 & 3.0 \\
\hline & Agree & 476 & 95.2 & 95.2 & 98.2 \\
\hline & Disagree & 9 & 1.8 & 1.8 & 100.0 \\
\hline & Total & 500 & 100.0 & 100.0 & \\
\hline \multicolumn{6}{|c|}{ Improved online presence } \\
\hline & & Frequency & Percent & Valid Percent & Cumulative Percent \\
\hline \multirow[t]{5}{*}{ Valid } & Strongly Agree & 42 & 8.4 & 8.4 & 8.4 \\
\hline & Agree & 412 & 82.4 & 82.4 & 90.8 \\
\hline & Neutral & 33 & 6.6 & 6.6 & 97.4 \\
\hline & \begin{tabular}{|l|} 
Disagree \\
\end{tabular} & 13 & 2.6 & 2.6 & 100.0 \\
\hline & Total & 500 & 100.0 & 100.0 & \\
\hline \multicolumn{6}{|c|}{ Preplanning and learning } \\
\hline & & Frequency & Percent & Valid Percent & Cumulative Percent \\
\hline \multirow[t]{5}{*}{ Valid } & Strongly Agree & 15 & 3.0 & 3.0 & 3.0 \\
\hline & Agree & 398 & 79.6 & 79.6 & 82.6 \\
\hline & Neutral & 44 & 8.8 & 8.8 & 91.4 \\
\hline & Disagree & 43 & 8.6 & 8.6 & 100.0 \\
\hline & Total & 500 & 100.0 & 100.0 & \\
\hline
\end{tabular}

\section{International Students}

Participants have agreed that different COVID 19 factors impacting International Students 
Table 3: COVID 19 factors impacting International Students

\begin{tabular}{|c|c|c|c|c|c|}
\hline \multicolumn{6}{|c|}{ Emotional distress } \\
\hline & & Frequency & Percent & Valid Percent & Cumulative Percent \\
\hline \multirow[t]{5}{*}{ Valid } & Strongly Agree & 27 & 5.4 & 5.4 & 5.4 \\
\hline & Agree & 419 & 83.8 & 83.8 & 89.2 \\
\hline & Neutral & 21 & 4.2 & 4.2 & 93.4 \\
\hline & Disagree & 33 & 6.6 & 6.6 & 100.0 \\
\hline & Total & 500 & 100.0 & 100.0 & \\
\hline \multicolumn{6}{|c|}{ Personal finances } \\
\hline & & Frequency & Percent & Valid Percent & Cumulative Percent \\
\hline \multirow[t]{5}{*}{ Valid } & \begin{tabular}{|l|} 
Strongly Agree \\
\end{tabular} & 15 & 3.0 & 3.0 & 3.0 \\
\hline & Agree & 408 & 81.6 & 81.6 & 84.6 \\
\hline & Neutral & 50 & 10.0 & 10.0 & 94.6 \\
\hline & Disagree & 27 & 5.4 & 5.4 & 100.0 \\
\hline & Total & 500 & 100.0 & 100.0 & \\
\hline \multicolumn{6}{|c|}{ Study concerns } \\
\hline & & Frequency & Percent & Valid Percent & Cumulative Percent \\
\hline \multirow[t]{5}{*}{ Valid } & \begin{tabular}{|l|} 
Strongly Agree \\
\end{tabular} & 21 & 4.2 & 4.2 & 4.2 \\
\hline & Agree & 403 & 80.6 & 80.6 & 84.8 \\
\hline & Neutral & 52 & 10.4 & 10.4 & 95.2 \\
\hline & \begin{tabular}{|l} 
Disagree \\
\end{tabular} & 24 & 4.8 & 4.8 & 100.0 \\
\hline & Total & 500 & 100.0 & 100.0 & \\
\hline \multicolumn{6}{|c|}{ Frustrated } \\
\hline & & Frequency & Percent & Valid Percent & Cumulative Percent \\
\hline \multirow[t]{5}{*}{ Valid } & \begin{tabular}{|l|} 
Strongly Agree \\
\end{tabular} & 15 & 3.0 & 3.0 & 3.0 \\
\hline & Agree & 411 & 82.2 & 82.2 & 85.2 \\
\hline & Neutral & 53 & 10.6 & 10.6 & 95.8 \\
\hline & Disagree & 21 & 4.2 & 4.2 & 100.0 \\
\hline & Total & 500 & 100.0 & 100.0 & \\
\hline
\end{tabular}

Five international students had communication with this author over the phone and discuss their financial and emotional distress during this pandemic.

International students were more worry about their graduation status and about their visa, optional practical training (OPT) opportunities were harder to obtained or sometimes canceled; either return back to home (if this is an option because of the border closings); living far away from loved ones without having strong network support; If dormitories were closed it was difficult to find a proper place to live, many students have loosed the jobs and some places do not have banking facilities because of the lockdown, so families were not able to send them money. One of an US international student and has completed multiple degrees and now working as a psychologist in the American University counseling center, according to him there were many complex factors such as, uncertainties and a sense of isolation because of Covid-19 that highly affect the mental health or many people especially international students. She who was doing master's in counseling in Thailand from Pakistan agrees that her academics were highly affected during this period, and so as mental health and personal life. During her internship period, she was counseling international students. Because of this outbreak, she observed that many students were experiencing similar effects. Another Indian students stated that the biggest fear among the international students was that they find no hope of being with their loved ones soon because of the flights' suspension. Moreover, she said her family is divided in three countries. This makes her more anxious and she was following news of all three places. Despite several negative aspects, many international students have illustrated the adaptability and admirable resilience during these times. When students get support from their universities and from their loved ones will be able to maintain their mental health.

\section{Impact on Tourism}

Participants have agreed that different COVID 19 factors impacting Tourism 
Table 4: COVID 19 factors impacting Tourism

\begin{tabular}{|c|c|c|c|c|c|}
\hline \multicolumn{6}{|c|}{ Harsh travel restrictions } \\
\hline & & Frequency & Percent & Valid Percent & Cumulative Percent \\
\hline \multirow[t]{5}{*}{ Valid } & Strongly Agree & 66 & 13.2 & 13.2 & 13.2 \\
\hline & Agree & 335 & 67.0 & 67.0 & 80.2 \\
\hline & Neutral & 36 & 7.2 & 7.2 & 87.4 \\
\hline & Disagree & 63 & 12.6 & 12.6 & 100.0 \\
\hline & Total & 500 & 100.0 & 100.0 & \\
\hline \multicolumn{6}{|c|}{ Few travelers } \\
\hline & & Frequency & Percent & Valid Percent & Cumulative Percent \\
\hline \multirow[t]{5}{*}{ Valid } & \begin{tabular}{|l|} 
Strongly Agree \\
\end{tabular} & 33 & 6.6 & 6.6 & 6.6 \\
\hline & Agree & 368 & 73.6 & 73.6 & 80.2 \\
\hline & Neutral & 39 & 7.8 & 7.8 & 88.0 \\
\hline & Disagree & 60 & 12.0 & 12.0 & 100.0 \\
\hline & Total & 500 & 100.0 & 100.0 & \\
\hline \multicolumn{6}{|c|}{ Financial loss } \\
\hline & & Frequency & Percent & Valid Percent & Cumulative Percent \\
\hline \multirow[t]{5}{*}{ Valid } & \begin{tabular}{|l|} 
Strongly Agree \\
\end{tabular} & 66 & 13.2 & 13.2 & 13.2 \\
\hline & Agree & 324 & 64.8 & 64.8 & 78.0 \\
\hline & Neutral & 47 & 9.4 & 9.4 & 87.4 \\
\hline & Disagree & 63 & 12.6 & 12.6 & 100.0 \\
\hline & Total & 500 & 100.0 & 100.0 & \\
\hline \multicolumn{6}{|c|}{ Lower working capital } \\
\hline & & Frequency & Percent & Valid Percent & Cumulative Percent \\
\hline \multirow[t]{5}{*}{ Valid } & \begin{tabular}{|l|} 
Strongly Agree \\
\end{tabular} & 21 & 4.2 & 4.2 & 4.2 \\
\hline & Agree & 374 & 74.8 & 74.8 & 79.0 \\
\hline & Neutral & 42 & 8.4 & 8.4 & 87.4 \\
\hline & Disagree & 63 & 12.6 & 12.6 & 100.0 \\
\hline & Total & 500 & 100.0 & 100.0 & \\
\hline
\end{tabular}

\section{Regression analysis}

The overall findings show the significant impact of the COVIA 19 on the individual performance concerning the small business, international student's performance as well as torusm sector showing the significant impact.

Table 4: Impact of COVID 19 factors on small businesses

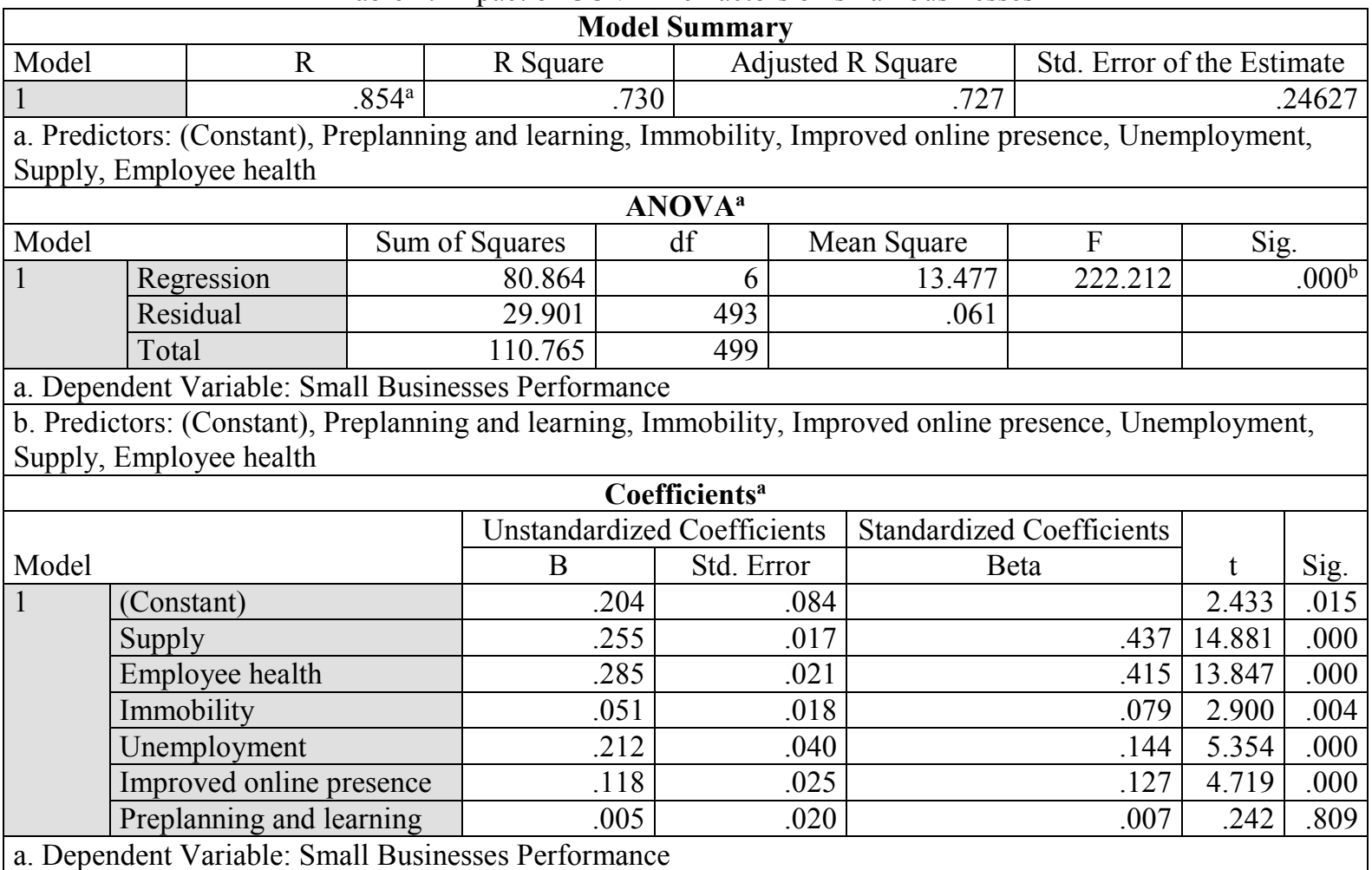


Table 5: Impact of COVID 19 factors on international students

\begin{tabular}{|c|c|c|c|c|c|c|c|c|}
\hline \multicolumn{9}{|c|}{ Model Summary } \\
\hline \multirow{2}{*}{\multicolumn{2}{|c|}{$\frac{\text { Model }}{1}$}} & & \multicolumn{2}{|c|}{ R Square } & \multicolumn{2}{|c|}{ Adjusted R Square } & \multicolumn{2}{|c|}{ Std. Error of the Estimate } \\
\hline & & $473^{\mathrm{a}}$ & \multicolumn{2}{|c|}{.224} & \multicolumn{2}{|r|}{.217} & \multicolumn{2}{|r|}{.42624} \\
\hline \multicolumn{9}{|c|}{ a. Predictors: (Constant), Frustrated, Emotional distress, Personal finances, Study concerns } \\
\hline \multicolumn{9}{|c|}{ ANOVA $^{\mathbf{a}}$} \\
\hline \multicolumn{2}{|c|}{ Model } & \multicolumn{2}{|c|}{ Sum of Squares } & \multicolumn{2}{|c|}{ df } & Mean Square & $\mathrm{F}$ & Sig. \\
\hline \multirow[t]{3}{*}{1} & Regression & & 25.896 & & 4 & 6.474 & 35.635 & $.000^{\mathrm{b}}$ \\
\hline & Residual & & 89.931 & & 495 & .182 & & \\
\hline & Total & & 115.827 & & 499 & & & \\
\hline \multicolumn{9}{|c|}{ a. Dependent Variable: International Students Performance } \\
\hline \multicolumn{9}{|c|}{ b. Predictors: (Constant), Frustrated, Emotional distress, Personal finances, Study concerns } \\
\hline \multicolumn{9}{|c|}{ Coefficients $^{\mathrm{a}}$} \\
\hline \multirow{2}{*}{\multicolumn{2}{|c|}{ Model }} & \multicolumn{4}{|c|}{ Unstandardized Coefficients } & $\begin{array}{l}\text { Standardized } \\
\text { Coefficients }\end{array}$ & & \\
\hline & & & $\mathrm{B}$ & Std. I & & Beta & $\mathrm{t}$ & Sig. \\
\hline \multirow[t]{5}{*}{1} & (Constant) & & 1.019 & & 103 & & 9.880 & .000 \\
\hline & Emotional distress & & .242 & & 036 & .296 & 6.649 & .000 \\
\hline & Personal finances & & .187 & & 039 & .217 & 4.749 & .000 \\
\hline & Study concerns & & -.045 & & .045 & -.053 & -.999 & .318 \\
\hline & Frustrated & & .160 & & .049 & .175 & 3.280 & .001 \\
\hline
\end{tabular}

Table 6: Impact COVID 19 factors on Tourism

\begin{tabular}{|c|c|c|c|c|}
\hline \multicolumn{5}{|c|}{ Model Summary } \\
\hline Model & $\mathrm{R}$ & R Square & Adjusted R Square & Std. Error of the Estimate \\
\hline 1 & $.987^{\mathrm{a}}$ & .974 & .974 & .07841 \\
\hline
\end{tabular}

a. Predictors: (Constant), Lower working capital, Few travelers, Financial loss, harsh travel restrictions

\begin{tabular}{|l|l|r|r|r|r|r|}
\hline \multicolumn{7}{|c|}{ ANOVA $^{\mathrm{a}}$} \\
\hline \multirow{2}{*}{ Model } & Sum of Squares & df & Mean Square & F & Sig. \\
\hline \multirow{3}{*}{1} & Regression & 112.784 & 4 & 28.196 & 4585.936 & $.000^{\mathrm{b}}$ \\
\cline { 2 - 8 } & Residual & 3.043 & 495 & .006 & & \\
\cline { 2 - 8 } & Total & 115.827 & 499 & & & \\
\hline
\end{tabular}

a. Dependent Variable: FP

b. Predictors: (Constant), Lower working capital, Few travelers, Financial loss, harsh travel restrictions

\begin{tabular}{|c|c|c|c|c|c|c|}
\hline \multicolumn{7}{|c|}{ Coefficients $^{\mathbf{a}}$} \\
\hline \multirow{2}{*}{\multicolumn{2}{|c|}{ Model }} & \multicolumn{2}{|c|}{ Unstandardized Coefficients } & \multirow{2}{*}{$\begin{array}{c}\text { Standardized } \\
\text { Coefficients } \\
\text { Beta }\end{array}$} & \multirow[b]{2}{*}{$\mathrm{t}$} & \multirow[b]{2}{*}{ Sig. } \\
\hline & & $\mathrm{B}$ & Std. Error & & & \\
\hline \multirow[t]{5}{*}{1} & (Constant) & .494 & .013 & & 37.257 & .000 \\
\hline & harsh travel restrictions & .270 & .025 & .459 & 10.980 & .000 \\
\hline & Few travelers & .229 & .006 & .357 & 41.495 & .000 \\
\hline & Financial loss & -.001 & .024 & -.002 & -.059 & .953 \\
\hline & Lower working capital & .256 & .006 & .392 & 42.248 & .000 \\
\hline
\end{tabular}

\section{Discussion}

\section{Impact of COVID on Tourism}

Business tours or business trips are somehow same in terms of events tourism education (Xiong et al., 2020). However, the difference lies in the event 'very essence, but mechanisms are mostly the same. Because of this fact Dubai and Abu Dhabi are considered as the most essential business centers for tour production (Xiong et al., 2020; Zhamgaryan, 2017). Many business congresses, conferences and diplomatic visits including the major business tourisms' drivers (Xiong et al., 2020). In tourism management and tourism infrastructure distinguish some principles on which many countries are rely on product topologies, territoriality research, tourism, also when there is an involvements of the public as well as private travel agencies along with the available companies, recreational opportunities, resources, service offers and tourist flows, selection of the tourism agency independently along with an independent choice of tourism agencies (Reitsamer \& Brunner - Sperdin, 2017). In this industry, an opportunity 
provided to world leaders through outsourcing in business tourism where they can communicate with their clients quickly and solve multiple problems, such as the global issue COVID-19 pandemic.

In order to survive, travel agencies efficiently use their all resources (Kuznetsov \& Kizyan, 2017). Through competitiveness ensure that survival is a dynamic process which aim is to get gain for long-term (Xiong et al., 2020). In the hospitality industry, the aim of managing corporate competitiveness is to establish sustainable competitiveness benefits at recovers the agencies' position and allow to perform financial activities in this postpandemic environment (Nukusheva et al., 2020).

According to many studies the competitiveness in this industry emphasis the significance of support and infrastructure service to maintain the sustainability of the environment (Croes, 2010; Xiong et al., 2020; Mihalic ', 2013; Zehrer et al., 2016).Competitiveness sector also includes managing of tourist behavior (Reisinger et al., 2019). Prior researches depend on survey tourism experts and important stakeholders of tourism (Andrades and Dimanche, 2019).

A research used a mixed-method to measure the industry's' competitiveness in Iran i.e. quantitative and qualitative methods (Boroomand et al., 2019). Others established their own indices to measure the competitiveness of the industry. For example, data taken from the competitiveness index of the Travel and tourism by the WEF to determine the industry competitiveness (Gómez-Vega and Picazo-Tadeo, 2019). While some authors used alternate information's sources (Gu et al., 2019; Lopes et al., 2018). The global country's tourism industry is highly affected by COVID-19.

The United Nations World Tourism Organization State that till May,2020 all the worldwide traveling were restricted because of the pandemic that has highly affected the each and every sector of the tourism industry such as, cruise lines, airlines, restaurants, hotels, attraction places such as, cultural heritage, protected areas, and national parks) tour operators travel agencies and online travel agencies. Micro firms, small and medium-size industries, which includes large tourism sectors, which covers $80 \%$ of the entire tourism sector, without having substantial support many people may not survive during the crises the entire tourism supply chain is domino affected by this pandemic and equally affected the other sectors such as fisheries, agriculture, and creative industries. In the MICE industry loss of jobs has affected the women and the indigenous population and youth disproportionately. Women operating companies and MICE operation companies are often small in size and having a minimum financial resource to survive during the crisis. In the tourism sector women holds some frontline positions such as, front desk and housekeeping staff, which put them at high risk (Gössling, Scott, \& Hall, 2020). World Bank state that, it is expected that World GDP is going to decline in 2020 by 5.21 percent (in 2019 the decline rate was 2.38 percent and going to raise in 2021 by 4.16 percent. however, the United Arab Emirates' GDP dynamics will encompass of -4.5 percent (comparing with 2019 GDP rate which will raise by 1.7 percent), and in 2021 it is expected to rise by 1.4 percent according to World Bank 2020. According to World Tourism Organization (2020), the promotion responsibility is taken by United Nation agency and also responsible to sustain and accessible tourism sector universally, as compare to 2019 the international tourism sector down fall was seen by $44 \%$

$$
\text { Asia and the Pacific } ⿴ \text { World }
$$
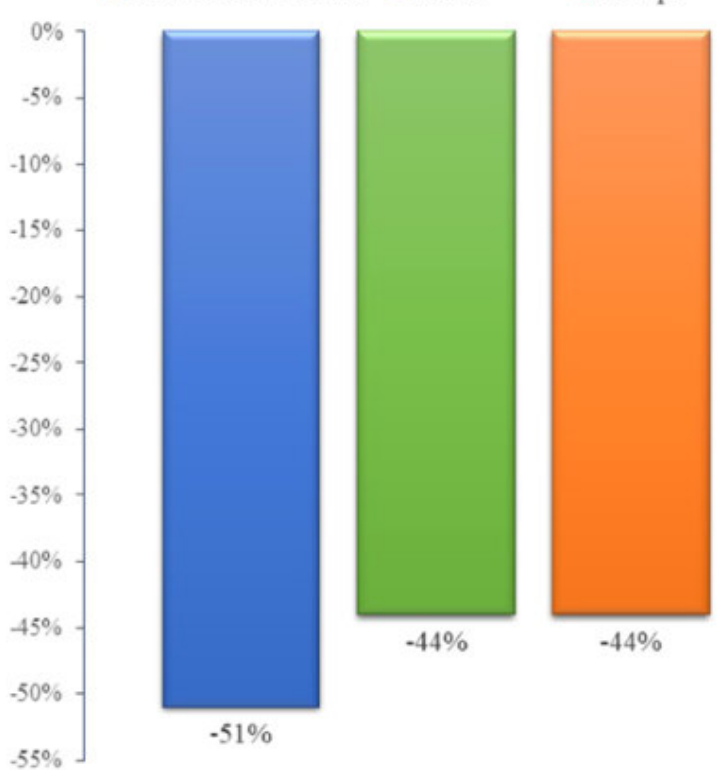


Figure. 1: International tourist \% (Source: WTO, 2020),

According to the figure 1, in January - April 2020 the significant decrease is seen in international arrivals experienced in the Pacific and Asia region by 51\% and in Europe 44\% and Middle East by $40 \%$. The decline in international arrivals is also seen in America by $36 \%$ and Africa by 35\% (Thakur \& Jain, 2020; UNWTO, June 22, 
2020). In initial may, three possible scenarios were suggested by UNWTO which shows the reduction in the entire international arrivals from 58 percent to 78 percent, depending on when the restrictions will be removed. In the middle of May when traveling resumes there is an increase in the amount of international arrivals increases. This includes the introduction of some extra safety and policies that were established regarding hygiene and safety aim to resume domestic traveling as well (World Tourism Organization, 2020b). Australia, New Zealand, Europe, Southeastern Asia Southern are those regions that experienced biggest drop in the international tourism

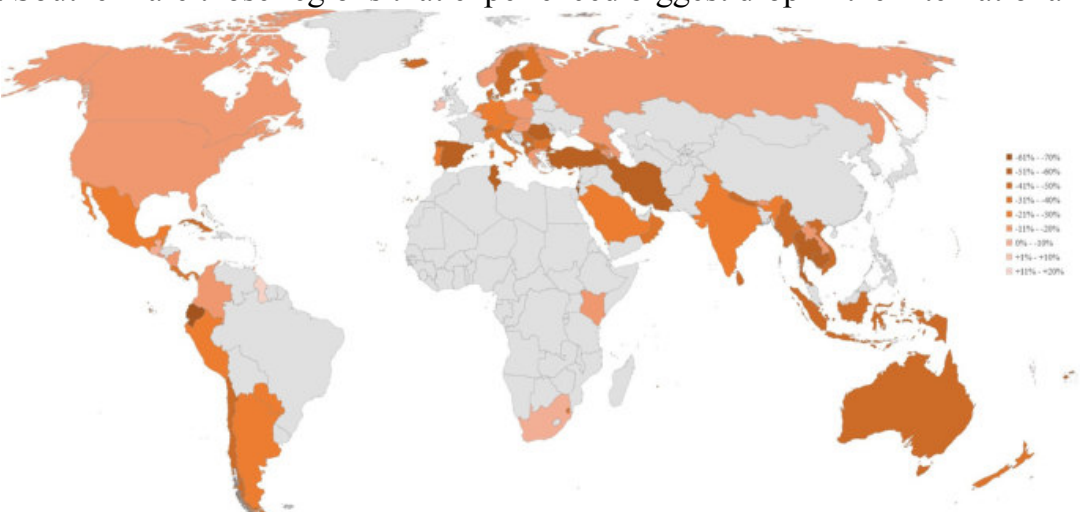

Figure 2: Countries international tourist Distribution (Source: WTO, 2020).

In spite, many countries have significant international arrivals positive values (Belgium, UAE, Ireland, Guyana, Jamaica, Vanuatu, Cayman Islands), According to the data of UNWTO established in Feburary 2020, stated that traveling with restrictions was not really severe. Similarly, other states also experienced low decreased results (Bhutan, Aruba, and Martinique).

\section{Impact of COVID 19 on Small Businesses.}

The reason for the major health crisis with frequent disastrous magnitudes and disturbed features of social and trade operations worldwide is labelled as Covid-19 pandemic, pushing around fifty percent of the global financial process under pressure. Micro, small and medium-sized enterprises (MSMEs) offer $70 \%$ of entire jobs, but with limited resources to handle the blizzard, putting them in to the category of helplessness due to the catastrophe, with the intensity growing for those in the third world countries and small island territories. The extensive closure of retail outlets and operations in the US and across the globe because of coronavirus is exceptional. Retail outlets, industries and operations went nonfunctional by a compulsive strategy, reduce want, health issues or rest of the elements. Numerous of such closings might go long-lasting due to the incapability of proprietors to bear the operational expenditures and persist the closure. The influence on minor companies across the globe is being predicted more intense.

The initial impact of COVID - 19 on minor companies and businesspersons are yet to know due to the scarcity of information pertaining to the business with in time by the government. The article discourses this restriction by inventing guesstimates of the several of proprietors from monthly Current Population Survey (CPS) micro data records. Utilizing this information within time, I inspect as to what is the COVID - 19 influence minor business proprietors in middle - April 2020 - the initial month to reduce the dissemination shelter - in - place constraints in the US. Later it extend the evaluation to add further two months in many regions that set boundaries initiated to reduce those limitations. CPS information are utilized for the Bureau of Labor Statistics (BLS) to trace the joblessness ratio, and have been utilized in past investigations to examine the devotions of the proprietors (e.g., Wang, 2019; Xiong et al., 2020; Thakur \& Jain, 2020). The CPS seizures the recent operation activities of the proprietors, and whether that proprietor is operating in present time. Therefore, the quantity of active proprietors can be included in the information, but informing whether the operations shutdown is for the time being or long lasting is difficult. Number of the inactive operation proprietors, however, appear to be nonoperational for long lasting basis, particularly if the COVID - 19 persuaded decline is sustained. Even transitory cessations affected by the pandemic are difficult as they translate revenue lost to the proprietors in that non-operational time.

This research reveal that initial assessment of the initial - stage properties of COVID - 19 on small business proprietors form CPS microdata. It was discover that the quantity of operational proprietors plunged from 15.0 million in $2^{\text {nd }}$ month of 2020 to about 11.7 million in $4^{\text {th }}$ month 2020 due to the pandemic COVID - 19 directives as well as health - and economic - driven mandate transferals. The harm of 3.3 million functional proprietors (or $22 \%$ ) was the major decline in files. When preparing on operational unevenly 2 or 4 days in a week, the damages are unfluctuating bigger (28 percent and 31 percent, respectively). Entire working hour hours for proprietors reduced by 29 percent. Though combined industries are more development oriented and steady, they faced a decline of 20 percent from February2020 to April 2020. Outlines across gender, race, and settler status appears to be highly concerned. African - Americans faced the huge losses, reducing 41 percent of functional proprietors. 
Latin also faced huge losses with 32 percent of proprietors with uncertain activities between Februarys as well as for April 2020. Settler proprietors agonized a huge decline of $36 \%$ in operational activities and female proprietors faced an unequal decline of 25 percent.

Outlets in whole country were shunted down because of the COVID - 19 directed constraints particularly in in April. Retail business display a decrease of 108,000 proprietors in April on behalf of 10\% of February 2020 levels. Functional proprietors in Retail business are simply somewhat decrease, though, in May and June. Cafes faced a decrease of $22 \%$ in April even though multiple of them left open revolved to take - out or home delivery facilities. The segment has faced enduring small operational activities for the upcoming two months. The wide segment of Arts, travel and hotels was harmed particularly firm decline of $35 \%$ in functional proprietors in April and necessarily no recovery.

Together high - and low expert services were smash tough by COVID - 19. Individual and Washing Services were particularly smashed hard with a loss of 79 percent of business proprietors' activities in April and enduring damages of 48 percent in May as well as 26 percent in June. Conveyance services which contains taxi and few Uber drivers plunged by $22 \%$ in April, but moderately recovered in following months. Higher expert services, like economical Activities and Proficient and Business facilities, lost 12\% and 18\%, respectively. Even healthcare facilities faced a plunged of $16 \%$. All three faced moderate recoveries in May and June.

It is also likely to classify the segments into necessary compare to unnecessary as per the region or domestic government strategies, though there is a loads of alterations in the strategies in the context of precise business segments. Delaware State offers the highly thorough and widespread list of necessary operations segments at the 4 - digit industry stage and tracks the same 4 - digit industry codes as the CPS (North American Industry Classification System, NAICS)6 The categorization seems to be flawed, however, as per the details, implementation, convenience of the proprietors, and healthcare and finance related clients' response differ throughout the country. Utilizing this classification, "necessary" business segment covers $76 \%$ of business proprietors. Losses in the quantity of operational business proprietors are less for necessary business at $17 \%$ in April equated with $38 \%$ between unnecessary business segments (as anticipated). Though both clusters of business proprietors faced some moderate recoveries, the quantity of operational business proprietors in necessary business segments was decreased by 10 percent in May and 5 percent in June, and the quantity in unnecessary business segments was decreased by 28 percent in May and 17 percent in June.

The initial assessment of the impact of COVID - 19 on the quantity of business proprietors from country wise representation in April-June 2020 CPS information refers intense initial level declines in minor business activities. The quantity of functional business proprietors in America dropped from 15.0 million to 11.7 million for the critical 2 - month gap from February to April 2020. No additional 1 - , 2 - , or even 12 - month gap of period has ever display that huge alteration in the operational activities. For evaluation, from the beginning to end of the Great Recession the quantity of functional business proprietors reduced by 730,000 demonstrating only a $5 \%$ decrease. Overall, business proprietors are comparatively stable for the business round (Parker, 2018). The loss of 3.3 million functional business proprietors (or 22 percent) was consist of of big declines in necessary sub clusters, like proprietors operating near about two days in a week (28 percent), Proprietors operating four days in a week (31 percent), and combined businesses (20 percent) When observed entirely in hours functioned by all business proprietors there was a decline of 29 percent.

It is well-established that COVID 19 has had a substantial adverse impact across the different sectors of the world (Gössling, Scott, \& Hall, 2020). The pandemic was first declared by the World health organization, where the confirmed cases were found to be initially at 200000 , with an exceeding death tool of 8000 across the 1600 countries in the world. Initially, China was affected by it, which further followed Italy, and then Europe, spreading across the different regions of the world (Xiong et al., 2020). Studies have presented that the economies (nationally) are substantially affected by the international, regional as well as local travel restrictions such as the domestic tourism, day visits, international travel, along with different segments such as the air transport, the cruise, public transport, accommodation as well as conventions, meetings, festivals as well as sports events (Gössling, Scott, \& Hall, 2020. The recovery endures in June 2020 raising the tally to additional seven percentage points. The plunge in business proprietor activities from February to June is $8 \%$. Though the recovery displays a broad emergence of small businesses, it endures to signify an exceptionally big decline in the business activities for the temporary timeframe. Prominently, the declines in the operational activities in April, May, and June signify huge revenue losses to business proprietors that cannot be completely recuperated.

African - American business proprietors experienced the highest plunged by COVID - 19. The initial assessments from April 2020 for African American business proprietors in America signify a huge decline of $41 \%$ in business activities. African American business proprietors were also unreasonably depressingly affected in May and June compare to the entire country levels in business activities of $26 \%$ and $19 \%$, separately. Estimations signify that the business segments distribution of African American was partially accountable, engaging African American business proprietors at high uncertain level of losses in business activities because of the pandemic. Latinx 
industries were also experienced huge losses by COVID - 19 dropping by $32 \%$ in functional business proprietors in April, $19 \%$ in May, and $10 \%$ in June. Asian business proprietors faced a $26 \%$ dropped in business activities throughout the crucial two months' gap, and endured losses operational activities by $21 \%$ in May and $10 \%$ in June. Calculation assessed also non supportive facts for the business distributions for Latinx, but the proof is minimum transparent for Asians. Settler business proprietors were also distressed with losses of $36 \%$ of business activities in April. Continued uneven losses were experienced in May (25\%) and June (18\%). Though industry disseminations located few clusters at maximum uncertainty of shunted in the pandemic, variances in the scale of trades are probably a main reason for uneven losses between small business proprietors, which are smaller normally (Fairlie \& Robb, 2008; U.S. Census Bureau, 2016). Bigger businesses are highly possible to have the capitals, business, and permitted structure, and revenues to apply measures to handle social distancing SOPs for functioning and recovering the operational activities during the pandemic.

The undesirable initial level influence on small business or the business owned by the settlers, if endured, can be difficult for widespread racism disparity due to the significance of minor business for domestic occupation generation (unreasonably signing rest of the minorities), financial development, and longer - term prosperity disparity (Boston, 1999, 2006; Bradford, 2003, 2014; Fairlie \& Robb, 2008; Stoll, Raphael, \& Holzer, 2001). With huge losses in operational activities in April and endured losses in May and June, even these sufferers were lesser, business proprietors have by now missed considerable quantity of revenues from their businesses. If an entire recovery does favors sooner than the persistent financial results can be more intense. Several minority business proprietors will not have the sources to whether lengthy closings, decrease demand from healthcare apprehensions, and a more widespread slump. The recent Census information signify that the average level of wealth between African American families is $\$ 13,000$ and Latinx families is $\$ 20,000$ equated with $\$ 139,000$ between white families (U.S. Census Bureau, 2015).

The initial assessment of initial level influence on functional female business proprietors are also annoying. Female business proprietorship is considerably lesser than male business proprietorship and female owned businesses have lesser incomes, personnel, and earnings normally (U.S. Census Bureau, 2016). The uneven losses in the initial three months to the activities by female business proprietors will simply develop gender biasness in business proprietors and possibly larger financial variation.

The subsequent necessary query is whether the closures of small operations are for the time being or are long lasting. The government has been answering to apprehensions for the prolonged tenure impact on small industries with the help of multiple initiatives. The leading initiative is the Paycheck Protection Program (PPP) which has therefore far allotted over $\$ 650$ billion to assist industries. Additional leading initiative is the Economic Injury Disaster Loan program by the Small Business Management, which offer more than \$150 billion as of July 2020 . Foundations and private organizations are also initiating to participate in the aid struggles. For instance, Magic Johnson Enterprises is offering a $\$ 100$ million obligation to minority - and female - retained companies left out of the PPP program. One more current instance, is the PayPal, in partnership with the Association for Enterprise Opportunity, invented a $\$ 10$ million fund to assist the African American proprietors, and Google is promising $\$ 175$ million on funding and supporting African American companies. Can these initiatives assist small companies persist the hindrances and closures because of the coronavirus pandemic, or will further support be required? More everlasting form shunted of small companies in America are possibly to have a drastic impact on human resources losing their jobs, more earning disparity, and participating to lengthy stagnation. But, the compromises from elevating the limitations on recovering of businesses on healthcare influences are yet to be known and of apprehension provided for COVID - 19 cases have been escalating throughout the summer (CDC, 2020b).

\section{International students and COVID-19}

Covid-19 was initially detected in Wuhan, China in December 2019, and has rapidly spread in all the countries and territories and severely affected the entire world. While completing this essay, around 380,000 death were reported from Covid-19 and 6 million new cases were registered worldwide (World Health Organization, 2020). According to health authorities, more than 90,000 cases and 8K deaths were reported from Covid-19. However, these statistics have staggering incredibly, and at this time considering this pandemic as a global health crisis .health experts determine that this disease is affecting every type of human being irrespective of gender, sex, race, class, the ethnicity of other social markers (WHO, 2020). However, there are some specific groups of people who are more vulnerable to this pandemic such as, older adults, indigenous people, low-income families, and people who are already going through some chronic and immune diseases (WHO, 2020). International students are also included in the list of those people who are highly vulnerable to this pandemic, who are harshly affected by the disease economically and socially by their migration status' virtue. Government policy responses are making focused on medical intervention for vaccine creation in order to minimize the spread of this disease (WHO, 2020), and implement emergency legislation such as social distancing, border closures and lockdowns that helps to stop the spread of this disease. Following government organization, international universities also closed their 
institutes because of the current health situation

To alleviate the economic and the social cost of the pandemic, the government is providing some social and financial relief to their vulnerable population. For instance, in Canada, these social and financial programs were organized by Canada Emergency Response Funds (CERB) and provide much Canadian social and economic security (The Globe and Mail, 2020). Unfortunately, international students cannot avail these relief programs as they are non-permanent residents. According to many studies, students from developing countries are already going through life circumstances such as, financial crises (e.g. Choudaha, 2017; McGill, 2013; Varghese, 2008). During the lockdown period and campus shutdown, many international students were gone through a sever state of anxiety and social and psychological distress, involving (1) sense of personal self-worth, (2) emotional distress,(3) academic performance affected (4) loss of interpersonal contacts (Miller, 2011; Regehr, 2011).

Moreover, it is also reported that there is an increase seen in prejudice, racism, and xenophobia that has highly affected international students' mental health.

Because of this pandemic many universities and colleges are now conducting their class online, as compared to domestic students, this mode of learning was more challenging for international students. According to the respondents, distant learning adds more stress in learning and people find this method more difficult to understand the concept when important things were even harder while seeing them on screen.

\section{Conclusion}

The findings have showed that there is a significant impact of the pandemic outbreak has led to the substantial downturn on the individuals. The impact is precisely high for the individuals that belong to the small business sector, are international students or operate in the tourism sector. However, there was no such negative impact of this pandemic on some international students and they even prefer it. Since this pandemic has left some adverse effect on the mental health of international students, and it has been recommended that universities should provide online counseling services. Many campuses have found this challenging and moving their online counseling service and providing counseling by phone, email, or video calls with no fee. There was some major issue possessed in online counseling. One of the major problematic issues faced by an international students who returned back to their homeland, licensing bodies were not allowed to provide counseling services to their clients in other provinces, states, and countries. Hence, students were not getting therapeutic services from their universities and may have discontinued their online counseling sessions. The survey showed that individual across the three sector has substantially been affected. This was due to the restricted mobilization which affected the trade as well as travelling. The international students further experienced emotional distress and found their life to be affected. However, the research also revealed that the businesses that worked online proliferated as a result of COVID 19.

\section{References}

Andrades L, Dimanche F (2019) Destination competitiveness in Russia: tourism professionals' skills and competences. Int J Contemp Hospit Manag 31 (2):910-930. https://doi.org/10.1108/IJCHM-11-2017-0769

Astakhova LV (2019) The concept of student cognitive culture: definition and conditions for development. Educ Sci J 21(10):89-115. https://doi.org/ 10.17853/1994-5639-2019-10-89-115. (In Russian)

Boroomand B, Kazemi A, Ranjbarian B (2019) Designing a model for competi- tiveness measurement of selected tourism destinations of Iran (the model and rankings). J Quality Assurance Hospit Tourism 20(4):491-506. https://doi. org/10.1080/1528008X.2018.1563015

Brouder P (2020) Reset redux: possible evolutionary pathways towards the trans- formation of tourism in a COVID-19 world. Tourism Geograph 1-7. https:// doi.org/10.1080/14616688.2020.1760928

Carlsson-Szlezak P, Reeves M, Swartz P (2020) What coronavirus could mean for the global economy. Harvard Business Rev 3: 1-10

Croes R (2010) Measuring and explaining competitiveness in the context of small island destinations J Travel Res 50(4):431-442. https://doi.org/10.1177/2F0047287510368139

Dubai Department of Tourism and Commerce Market (2020) Dubai Annual Visitor Report 2019. July, 2020. https://dubaitourism.getbynder.com/m/ 3e56c8625ed93ce0/original/DTCM-ANNUAL-REPORT-2019EN.pdf. Last assessed: 17/07/2020

Dubai Tourism (2020) Dubai Corporation of Tourism and Commerce Marketing. http://www.visitdubai.com/enus/department-of-tourism new/about-dtcm/ tourism-vision-2020

Dubai World Trade Centre (2019) DWTC drives record AED 13.1bn in net eco- nomic value and 3.3\% impact to city's GDP in 2018. Press Release. https:// www.dwtc.com/en/press/dwtc-events-fuel-dubais-economy-2019

DuPont Model (2015) Calculation formula. 3 Modifications. Finance for Dummies (March 18, 2015). Date of treatment May 24, 2016

Dwyer L, Armenski T, Cvelbar LK, Dragićević V, Mihalic T (2016) Modified Importance-performance analysis for evaluating tourism businesses strate- gies: comparison of Slovenia and Serbia. Int J Tourism Res 
18(4):327-340. https://doi.org/10.1002/jtr.2052

Emerald Expert Briefings, (oxan-db)

Gómez-Vega M, Picazo-Tadeo AJ (2019) Ranking world tourist destinations with a composite indicator of competitiveness: to weigh or not to weigh? Tourism Manag 72:281-291. https://doi.org/10.1016/j.tourman.2018.11.006

Gössling S, Scott D, Hall CM (2020) Pandemics, tourism and global change: a rapid assessment of COVID-19. J Sustain Tourism. 1-20. https://doi.org/10.1080/ 09669582.2020.1758708

Gössling, S., Scott, D., \& Hall, C. M. (2020). Pandemics, tourism and global change: a rapid assessment of COVID-19. Journal of Sustainable Tourism, 1-20.

Gu T, Ren P, Jin M, Wang H (2019) Tourism destination competitiveness eva- luation in Sichuan province using TOPSIS model based on information entropy weights. Discrete Continuous Dynam Syst-S 12(4-5):771-782. https://doi.org/10.3934/dcdss.2019051

Hao, F., Tan, W., Jiang, L., Zhang, L., Zhao, X., Zou, Y., ... \& Tran, B. (2020). Do psychiatric patients experience more psychiatric symptoms during COVID-19 pandemic and lockdown? A case-control study with service and research implications for immunopsychiatry. Brain, behavior, and immunity.

Higgins-Desbiolles F (2020) Socialising tourism for social and ecological justice after COVID-19. Tourism Geograph 1-14. https://doi.org/10.1080/ 14616688.2020.1757748

Holloway JC, Humphreys C (2019) The business of tourism. SAGE Publications Limited

Hoque A, Shikha FA, Hasanat MW, Arif I, Hamid ABA (2020) The effect of Coronavirus (COVID-19) in the tourism industry in China. Asian J Multi- discipl Stud 3(1):52-58

Iacus SM, Natale F, Santamaria C, Spyratos S, Vespe M (2020) Estimating and projecting air passenger traffic during the COVID-19 coronavirus outbreak and its socio-economic impact. Safety Sci 104791. https://doi.org/10.1016/j. ssci.2020.104791

It Pulse (2019) What is outsourcing and what is it useful for business http://it- pulse.com.ua/chto-takoe-autsorsingi-chem-on-polezen-dlya-biznesa.html

Jovanović S, Ilić I (2016) Infrastructure as important determinant of tourism development in the countries of Southeast Europe. Ecoforum 5 (1):288-294

Kastenholz E, Eusebio C, Figueiredo E, Lima J (2012) Accessibility as competitive advantage of a tourism destination: the case of Lousã. In K Hyde, Ryan C, Woodside A (eds) Field guide to case study research in tourism, hospitality and leisure (Advances in Culture, Tourism and Hospitality Research) (Vol. 6) Emerald Publishing Ltd, pp. 369-385

Kuznetsov YuV, Kizyan NG (2017) Features of the choice of competitiveness strategy at the enterprises of the tourism industry. Manag Consult 9 (105):74-81. https://doi.org/10.22394/1726-1139-2017-9-74-81

Lopes APF, Muñoz MM, Alarcón-Urbistondo P (2018) Regional tourism compe- titiveness using the PROMETHEE approach. Ann Tourism Res 73:1-13. https://doi.org/10.1016/j.annals.2018.07.003

Mamun, M. A., \& Ullah, I. (2020). COVID-19 suicides in Pakistan, dying off not COVID-19 fear but poverty?The forthcoming economic challenges for a developing country. Brain, behavior, and immunity.

Manzoor F, Wei L, Asif M (2019) The contribution of sustainable tourism to economic growth and employment in Pakistan. Int J Environ Res Public Health 16(19):3785. https://doi.org/10.3390/ijerph16193785

Mazurek M (2014) Competitiveness in tourism-models of tourism competitiveness and their applicability. Eur J Tourism Hospital Recreat 1:73-94

McIntyre, R. S., \& Lee, Y. (2020). Projected increases in suicide in Canada as a consequence of COVID-19. Psychiatry research, 113104.

Mihalic ${ }^{`} \mathrm{~T}$ (2013) Performance of environmental resources of a tourist destination: concept and application. J Travel Res 52(5):614-630. https://doi.org/10.1177/0047287513478505

Nazmfar H, Eshghei A, Alavi S, Pourmoradian S (2019) Analysis of travel and tourism competitiveness index in middle-east countries. Asia Pacific J Tourism Res 24(6):501-513. https://doi.org/10.1080/10941665.2019.1590428

Nicola M, Alsafi Z, Sohrabi C, Kerwan A, Al-Jabir A, Iosifidis C, Agha M, Agha R (2020) The socio-economic implications of the coronavirus pandemic (COVID-19): a review. Int J Surgery 78:185. https://doi.org/10.1016/j. ijsu.2020.04.018

Nukusheva A, Ilyassova G, Kudryavtseva L, Shayakhmetova Z, Jantassova A, Popova L (2020) Transnational corporations in private international law: do Kazakhstan and Russia have the potential to take the lead? Entrepre Sustain Issues 8(1):496-512

OAG. Flight Database \& Statistics, Aviation Analytics (2020). Available at: www. oag.com. Last accessed: $16 / 07 / 2020$

Oxford Analytica (2020) COVID-19 and oil shocks raise Gulf recession risks.

Pulido-Fernández JI, Cárdenas-García PJ, Espinosa-Pulido JA (2019) Does envir- onmental sustainability contribute to tourism growth? An analysis at the country level. J Cleaner Product 213:309-319. 
https://doi.org/10.1016/j. jclepro.2018.12.151

Reisinger Y, Michael N, Hayes JP (2019) Destination competitiveness from a tourist perspective: a case of the United Arab Emirates. Int J Tourism Res 21 (2):259-279. https://doi.org/10.1002/jtr.2259

Reitsamer B, Brunner - Sperdin A (2017) Tourist destination perception and well - being. J Vacation Market 23(1):55-72. https://doi.org/10.1177/ 1356766715615914

Rogerson CM (2017) Tourism-a new economic driver for South Africa. In: Lemon A, Rogerson CM (eds) Geography and economy in South Africa and its neighbours. Routledge, pp. 95-110

Sable K, Roy A, Deshmukh R (2019) MICE Industry by Event Type (Meeting, Incentives, Conventions, and Exhibitions): Global Opportunity Analysis and Industry Forecast, 2018-2025. MICE Industry Outlook-2025. Allied Market Research. https://www.alliedmarketresearch.com/MICE-industry- market

Safarova NN (2015) Analysis of national competitiveness of tourism and travel: conclusions for the CIS countries. Econ Analy 30(429):53-64

Siddiquei MI, Khan W (2020) Economic implications of coronavirus. J Public Affairs https://doi.org/10.1002/pa.2169

Sovet K, Salima S, Altynay M (2016) Trends in the development of business tourism in the Republic of Kazakhstan. Probl Modern Sci Educ 40 (82):1-9

Standard Country or Area Codes for Statistics Use (1999). The United Nations. Series: M, No. 49/Rev.4 (M49 standard). Online version. https://unstats.un. org/unsd/methodology/m49/

Statista (2020) Global № 1 Business Data Platform. https://www.statista.com/ statistics/734587/uae-domesticexpenditure-as-contribution-to-gdp/

Stock JH (2020) Reopening the Coronavirus-Closed Economy (Vol. 60). Technical Report. Hutchins Center Working Paper

Suvorova IN (2012) Corporate business tourism outsourcing. Russian Entrepre 12 (210):161-166

Tan, W., Hao, F., McIntyre, R. S., Jiang, L., Jiang, X., Zhang, L., ... \& Zhang, Z. (2020). Is returning to work during the COVID-19 pandemic stressful? A study on immediate mental health status and psychoneuroimmunity prevention measures of Chinese workforce. Brain, behavior, and immunity.

Thakur, V., \& Jain, A. (2020). COVID 2019-suicides: A global psychological pandemic. Brain, behavior, and immunity.

Tsindeliani I (2019) Public financial law in digital economy. Informatologia 52 (3-4):185-193

Twining Ward L, McComb JF (2020) COVID-19 and Tourism in South Asia: opportunities for sustainable regional outcomes. World Bank, Washington, DC

Tymchyshyn-Chemerys JV, Pasternak OI (2017) Directly, the competitiveness of the tourism industry in Ukraine. Int Sci J Int Sci 7:165-171

Wang, C., Pan, R., Wan, X., Tan, Y., Xu, L., Ho, C. S., \& Ho, R. C. (2020). Immediate psychological responses and associated factors during the initial stage of the 2019 coronavirus disease (COVID-19) epidemic among the general population in China. International journal of environmental research and public health, 17(5), 1729.

World Bank (2020) Global Economic Prospects, June 2020. Washington, DC. https://openknowledge.worldbank.org/handle/10986/33748. Last assessed: 10/07/2020

World Tourism Organization (2020a) New Data Shows Impact of COVID-19 on Tourism as UNWTO Calls for Responsible Restart of the Sector, June 22, 2020. https://www.unwto.org/news/new-data-shows-impact-ofcovid-19-on- tourism. Last assessed: 10/07/2020

World Tourism Organization (2020b) UNWTO World Tourism Barometer May 2020. Special focus on the Impact of COVID-19 (Summary). Retrieved from: https://webunwto.s3.eu-west-1.amazonaws.com/s3fspublic/2020-05/Barometer\%20-\%20May\%202020\%20-\%20Short.pdf. Last assessed: 17/07/2020

World Tourism Organization (2020c) International Tourism and covid-19 UNWTO online resource. Retrieved from: https://www.unwto.org/ international-tourism-and-covid-19. Last assessed: 15/07/2020

World Travel and Tourism Council (2020) Guidelines for WTTC's Safe and Seamless Traveler Journey - Testing, Tracing and Health Certificates, June 2020. https://www.prevuemeetings.com/coronavirus/wttc-travelguidelines/. Last assessed: 15/07/2020

Xiong, J., Lipsitz, O., Nasri, F., Lui, L. M., Gill, H., Phan, L., ... \& McIntyre, R. S. (2020). Impact of COVID-19 pandemic on mental health in the general population: A systematic review. Journal of affective disorders.

Zehrer A, Smeral E, Hallmann K (2016) Destination competitiveness: a comparison of subjective and objective indicators for winter sports areas J Travel Res 56 (1):55-66. https://doi.org/10.1177/2F0047287515625129

Zhamgaryan GA (2017) History of Tourism Development in the Arabian Coun- tries on the Example of Jordan and the UAE. St. Petersburg 